Human and Animal Health

Vol.60: e17160333, January-December 2017 http://dx.doi.org/10.1590/1678-4324-2017160333 ISSN 1678-4324 Online Edition

\title{
Odanacatib Inhibits Resistin-induced Hypertrophic H9c2 Cardiomyoblast Cells Through LKB1/AMPK Pathway
}

\author{
Xian Zheng ${ }^{1}$, Huzi Liu ${ }^{1}$, Guanchang Cheng ${ }^{2}$, Jianwei Luo ${ }^{1}$, Qunhui Ye², Yongzhi Deng ${ }^{1}$, \\ Lin $\mathbf{W u}^{2,3}$. \\ ${ }^{1}$ The Affiliated Cardiovascular Hospital of Shanxi Medical University, and Shanxi Cardiovascular Hospital - \\ Department of Cardiovascular Surgery, Taiyuan, Shanxi, China; ${ }^{2}$ Huaihe Hospital of Henan University - \\ Department of Cardiology, Kaifeng, Henan, China; ${ }^{3}$ The Affiliated Wenling Hospital of Wenzhou Medical \\ University - Department of Cardiology, Wenling, Zhejiang, China.
}

\begin{abstract}
Odanacatib $(O D N)$ is a selective inhibitor of cathepsin $K$. The cysteine protease cathepsin $K$ has been implicated in cardiac hypertrophy. Resistine is an adipokine which is identified to promote cardiac hypertrophy. Here, we hypothesize that ODN mitigates resistin-induced myocyte hypertrophy. Cell surface area and protein synthesis were measured after treatment with resistin and ODN in H9c2 cells. The expression of cardiomyocyte hypertrophy marker BNP and $\beta$-MHC was detected by RT-qPCR. The expression and phosphorylation of AMPK and LKB1 were analyzed with Western blot. Resistin could significantly increase cardiomyocyte cell surface area, protein synthesis, and embryonic gene BNP and $\beta$-MHC expression, inhibit phosphorylation of AMPK and LKB1. ODN could significantly reverse the effects of resistin. Collectively, our data suggest that ODN can inhibit cardiomyocyte hypertrophy induced by resistin and the underlying mechanism may be involved in LKB1/AMPK pathway.
\end{abstract}

Key words: Resistin, Odanacatib, LKB1/AMPK pathway, Cardiomyocyte hypertrophy

\footnotetext{
*Author for correspondence: 13834591065@163.com
} 


\section{INTRODUCTION}

Cardiac hypertrophy is compensatory changes of cardiomyocytes caused by all kinds of mechanical stimulation, oxidative stress, neural endocrine hormone and cytokine stimulation. Cardiac hypertrophy is characterized by increased myocardial cell size and protein synthesis, recurrence of fetal genes, change of contraction force and so on. A certain degree of hypertrophy can be compensated, and maintain the normal function of the heart. But continued hypertrophy eventually results in decompensation and lead to change of the structure and function of the heart, and develop to heart failure in the end. Therefore actively control the development of cardiac hypertrophy is important to control the occurrence of heart failure development. It is reported that celecoxib can prevent cardiac hypertrophy and dysfunction by inhibiting apoptosis, inflammation and oxidative stress ${ }^{1}$. KMUP-1 attenuates endothelin-1-inducd cardiomyocyte hypertrophy through suppression of the Akt/GSK-3 $\beta$ pathway ${ }^{2}$.

Resistin is a kind of adipokine. It has the effect of insulin resistance. Human resistin gene is located on the 19th chromosome and the molecular weight is $12.5 \mathrm{KDa}$. Many researchers found that resistin is associated with diseases such as obesity, diabetes and cardiovascular disease. In the myocardial tissue of patients with diabetes, resistin levels are increased significantly ${ }^{3}$. Resistin can destroy glucose metabolism in myocardial cells, which affects the structure and function of the heart ${ }^{4}$. Recombinant human resistin can aggravate myocardial ischemia-reperfusion injury and increase expression of ANP and BNP via NF- $\mathrm{kB}$ signaling pathway ${ }^{5}$. Resistin is mainly expressed in infarction lesions in animal models of myocardial infarction $^{6}$. Resistin can reduce human coronary artery endothelial nitric oxide synthase expression ${ }^{7}$, increase its permeability ${ }^{8}$ and stimulate monocytes infiltration ${ }^{9}$. Excessive expression of resistin not only promotes myocardial tissue fibrosis, cell apoptosis and oxidative stress but also reduces the contraction force and changes structure of the heart ${ }^{10}$.

Cathepsins belong to lysosomal proteases and play important roles in cardiovascular diseases ${ }^{11}$. Cathepsin $\mathrm{K}$ (Cat $\left.\mathrm{K}\right)$ is one of the most important enzymes in the family of lysosomal proteases. Cathepsin $\mathrm{K}$ was found in inflammatory macrophages first, it is the key of bone resorption protease ${ }^{12,}{ }^{13}$. The expression of cathepsin $\mathrm{K}$ is obviously higher in the myocardial tissue of patients with heart failure, dilated and hypertrophic cardiomyopathy ${ }^{14,15}$. The expression of cathepsin $\mathrm{K}$ is closely related to the development of chronic heart failure, and cathepsin $\mathrm{K}$ can be used as a biomarker of cardiac remodeling and dysfunction ${ }^{16}$. ODN is a selective and reversible inhibitor of cathepsin K. A large number of clinical and experimental studies have found that ODN treatment for osteoporosis has obvious effects ${ }^{17}$. ODN can interfere with a variety of precursor and mature cathepsin K transport pathways. The aim of the this study was to evaluate the effects of ODN on resistin-induced cardiacmyocyte hypertrophy.

\section{MATERIALS AND METHODS}

\section{Reagents}

Odanacatib was ordered from Selleckchem (Houston, TX, USA). Recombinant human resistin was purchased from PeproTech, Inc. (Rocky Hill, NJ, USA). H9c2 rat cardiomyoblast cells were obtained from the American Type Culture Collection (Manassas, VA, USA). Fetal bovine serum (FBS) was purchased from Zhejiang Tianhang Biological Technology (Zhejiang, China). Antibodies raised against phosphor-LKB1, LKB1, phosphor-AMPK and AMPK were purchased from Cell Signaling Technology, Inc. (Danvers, MA, USA). The UNIQ-10 column TRIzol® 
ODN inhibits resistin-induced myocyte hypertrophy

kit was ordered from Sangon Biotech Co., Ltd. (Shanghai, China). PrimeScript ${ }^{\circledR R T}$ Master Mix Perfect Real Time and SYBR ${ }^{\circledR}$ Premix Ex Taq ${ }^{\mathrm{TM}}$ II were obtained from Takara (Tokyo, Japan).

\section{H9c2 cell culture}

H9c2 rat cardiomyoblast cells were cultured in DMEM containing 10\% FBS, $1 \%$ penicillin and $1 \%$ penicillin/streptomycin at a temperature of $37^{\circ} \mathrm{C}$ with a $5 \% \mathrm{CO} 2$ atmosphere. Once cells had covered the area of culture bottle bottom $70 \%$ to $80 \%$, they were passaged according to a 1:2 or 1:3 proportion. The medium was changed every 2 days. Cells were seeded into a $3.5 \mathrm{~cm}^{2}$ culture dish at a density of $1 \times 10^{5}$. Cells were cultured overnight, and then replaced the medium with serumfree medium for $24 \mathrm{~h}$. Cells were treated with resistin at a concentration of 50 $\mathrm{ng} / \mathrm{ml}^{18}$ and ODN at a concentration of $300 \mathrm{nM}^{19}$ for the indicated time.

\section{Determination of cell surface area}

$8 \times 10^{4}$ cells were seeded into $3.5 \mathrm{~cm}^{2}$ dishes. Cells were cultured with serum-free DMEM for $24 \mathrm{~h}$. Cells were treated with resistin for $48 \mathrm{~h}$ or treated with ODN for 2 $\mathrm{h}$ and then replaced it with resistin for $46 \mathrm{~h}$. The cell surface area was measured with ImageJ software (NIH ImageJ version 1.49 software, Bethesda, MD, USA). Five observation fields were selected at random and 10 cells in each observation field were selected for measurement of cell surface area ${ }^{18}$.

\section{Protein synthesis measurement}

$1 \times 10^{5}$ cells were seeded into $3.5 \mathrm{~cm}^{2}$ dishes. After cells were cultured with serumfree DMEM for $24 \mathrm{~h}$, cells were treated with resistin for $48 \mathrm{~h}$ or treated with ODN for $2 \mathrm{~h}$ and then replaced it with resistin for $46 \mathrm{~h}$. The cells were collected and lysed in $70 \mu \mathrm{l}$ of total protein lysis buffer. Protein concentrations were detected by BCA protein quantitative kit (Boster, Wuhan, China). Cell protein synthesis was determined by dividing the total amount of protein by the cell number ${ }^{18}$.

\section{Reverse transcription-quantitative polymerase chain reaction (RT-qPCR)}

RNA was extracted using the UNIQ-10 column TRIzol kit (Shanghai Sangon Biotech, Shanghai, China) and treated with DNase. A total of $1 \mu \mathrm{g}$ of RNA was reverse transcribed to cDNA using the PrimeScript ${ }^{\circledR R T}$ Master Mix Perfect RealTime Kit (Takara). According to the manufacturer's instructions, PCR amplification was conducted with SYBR ${ }^{\circledR}$ Premix Ex Taq ${ }^{\mathrm{TM}}$ II kit (Takara) using the Applied Biosystems ${ }^{\circledR} 7500$ Fast Real-Time PCR System (Thermo Fisher Scientific Inc., Waltham, MA, USA). The PCR reaction condition was: $95^{\circ} \mathrm{C}$ for $10 \mathrm{~min}, 95^{\circ} \mathrm{C}$ for $15 \mathrm{sec}$, and then 40 cycles of $60^{\circ} \mathrm{C}$ for $1 \mathrm{~min}$. GAPDH was used as a reference gene. The Cq method was used for relative quantification. The BNP, $\beta$-MHC and GAPDH primers were designed and synthesized by Shanghai Sangon Biotech Co., Ltd. The nucleotide sequences of the primers were as follows: BNP forward, 5'TCTGGGACCACCTCTCAAGT-3' and reverse, ${ }^{\prime}$ 'GGCAAGTTTGTGCTGGAAGA-3'; $\quad \beta$-MHC forward, $\quad 5^{\prime}$ CAGAACACCAGCCTCATCAA-3' and reverse, ${ }^{\prime}$ 'CCTCTGCGTTCCTACACTCC-3'; GAPDH forward, 5'ATCACCATCTTCCAGGAGCGA-3' and reverse, ${ }^{\prime}$ ' AGCCTTCTCCATGGTGGTGAA-3'.

\section{Western blot analysis}

Cells were collected and lysed to prepare protein. The protein concentration was measured with BCA kit (Beyotime Biotechnology, Beijing, China). 5X SDS-PAGE 
protein loading buffer (Boster, Wuhan, China) was added to samples, which were heated at $100^{\circ} \mathrm{C}$ for $5 \mathrm{~min}$. The proteins were separated by $12 \%$ sodium dodecyl sulfate polyacrylamide gel electrophoresis. The proteins were transferred onto polyvinylidene fluoride membranes (EMD Millipore, Billerica, MA, USA). The membranes were blocked with TBST buffer $(20 \mathrm{mM}$ Tris-HCl, $150 \mathrm{mM} \mathrm{NaCl}$ and $0.1 \%$ Tween-20) containing 5\% non-fat milk for $1 \mathrm{~h}$ at room temperature. The membranes were incubated in TBST buffer containing 5\% non-fat milk with the primary antibodies p-LKB1 (cat. no. 3482S; monoclonal rabbit anti-rat; 1:1,000; Cell Signaling Technology, Inc.), LKB1 (cat. no. 3047S; monoclonal rabbit anti-rat; 1:1,000; Cell Signaling Technology, Inc.), p-AMPK (cat. no. 2531S; polyclonal rabbit anti-rat; 1:1,000; Cell Signaling Technology, Inc.), AMPK (cat. no. 5831S; monoclonal rabbit anti-rat; 1:1,000; Cell Signaling Technology, Inc.), $\beta$-actin (cat. no. 4967S; polyclonal rabbit anti-rat; 1:1,000; Cell Signaling Technology, Inc.) at $4^{\circ} \mathrm{C}$ overnight. After primary antibodies incubation, the membranes were incubated with anti-rabbit secondary antibodies (cat. no. 111-035-003; polyclonal goat-anti rabbit; 1:10,000; Jackson ImmunoResearch, Inc., West Grove, PA, USA) conjugated to horseradish peroxidase at room temperature for $1 \mathrm{~h}$. The protein bands were visualised using an chemiluminescence kit (Boster, Wuhan, China) and FluorChem ${ }^{\mathrm{TM} Q}$ Quantitative Western Blot Imaging System (Bio-Techne, Minneapolis, MN, USA). The ratio of phosphorylated/unphosphorylated protein was measured with ImageJ software.

\section{Statistical analysis}

SPSS 17.0 statistical software was used for data analysis. All experiments data were expressed as means \pm SD. The comparison between multiple groups which satisfied with the normality and homogeneity of variance, the single factor analysis of variance was used, and pairwise comparison with LSD-t method. $\mathrm{p}<0.05$ is statistically different.

\section{RESULTS}

ODN treatment decreases $\mathrm{H9c2}$ cell surface area which is increased by resistin $\mathrm{H} 9 \mathrm{c} 2$ cells were treated with resistin at $50 \mathrm{ng} / \mathrm{ml}$ for $48 \mathrm{~h}$. Resistin increased cell surface area significantly compared to the control group ( $\mathrm{p}<0.01$, Fig. 1). H9c2 cells were pretreated with ODN at $300 \mathrm{nM}$ for $2 \mathrm{~h}$ and then treated with resistin. ODN significantly decreased cell surface area compared to the resistin group ( $\mathrm{p}<$ 0.01, Fig. 1).

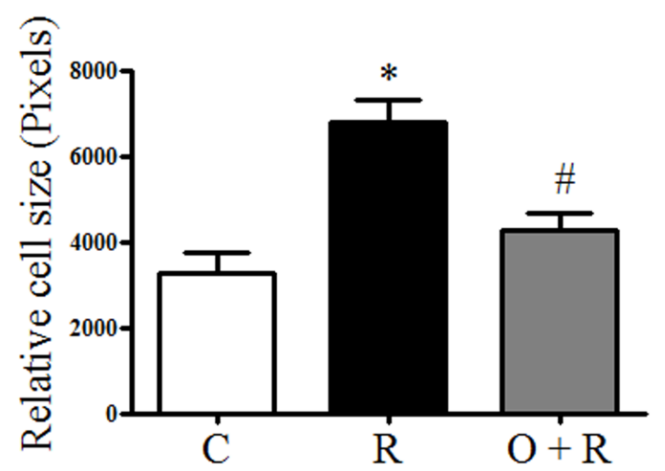

Figure 1 - Effects of ODN on cell surface area increased by resistin. Cell surface areas were measured using ImageJ software. Data represent the mean $\pm \mathrm{SD}$. ${ }^{*} \mathrm{p}<0.01$ vs. the control group, $\# \mathrm{p}<0.01$ vs. the resistin group. C, control; $\mathrm{R}$, resistin; $\mathrm{O}+\mathrm{R}$, resistin + odanacatib. 

ODN opposes the effect of resistin that increases cardiomyocyte protein
synthesis

To investigate whether ODN treatment decreases resistin-induced protein synthesis in $\mathrm{H} 9 \mathrm{c} 2$ cells, $\mathrm{H} 9 \mathrm{c} 2$ cells were treated with resistin at $50 \mathrm{ng} / \mathrm{ml}$ for $48 \mathrm{~h}$. Resistin increased protein synthesis significantly compared to the control group $(\mathrm{p}<0.01$, Fig. 2). H9c2 cells were pretreated with ODN at $300 \mathrm{nM}$ for $2 \mathrm{~h}$ and then treated with resistin. ODN significantly decreased protein synthesis that was increased by resistin ( $\mathrm{p}<0.01$, Fig. 2).

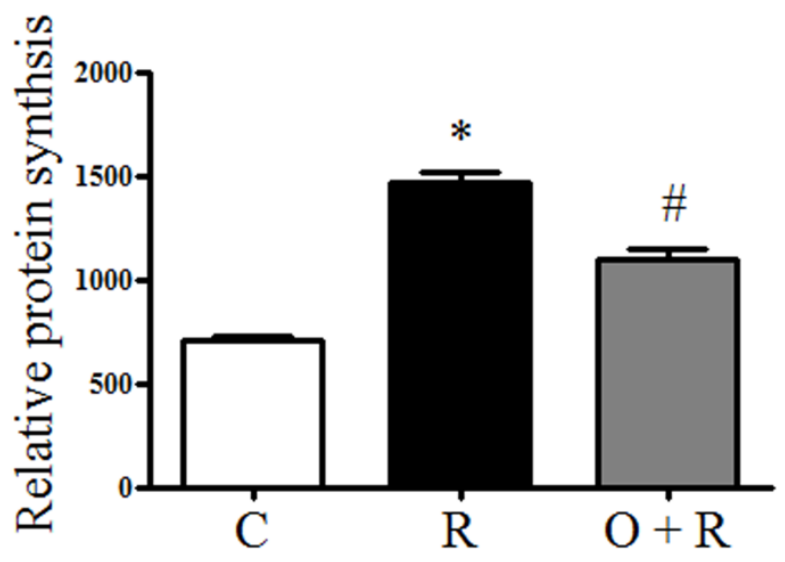

Figure 2 - Effects of ODN on cell protein synthesis enhanced by resistin. Cell protein concentration were measured and normalized to the cell number. Data represent the mean \pm SD. $* p<0.01$ vs. the control group, \#p $<0.01$ vs. the resistin group. $\mathrm{C}$, control; $\mathrm{R}$, resistin; $\mathrm{O}+\mathrm{R}$, resistin + odanacatib.

ODN treatment suppresses the mRNA expression levels of BNP and $\beta$-MHC increased by resistin

BNP and $\beta$-MHC are markers of cardiomyocyte hypertrophy. The effects of ODN treatment on the expression of BNP and $\beta$-MHC mRNA were investigated in H9c2 cells. The results demonstrated that ODN treatment suppressed the expression of BNP and $\beta$-MHC mRNA induced by resistin ( $p<0.01$, Fig. 3A, B).

A B
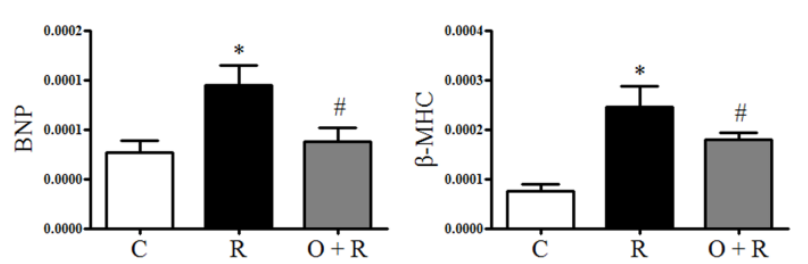

Figure 3 - ODN decreases BNP and $\beta$-MHC mRNA expression that is increased by resistin. (A) BNP mRNA and (B) $\beta$-MHC mRNA levels were examined by reverse transcription quantitative PCR. Data represent the mean \pm SD. ${ }^{*} \mathrm{p}<0.01$ vs. the control group, \#p < 0.01 vs. the resistin group. $\mathrm{C}$, control; R, resistin; $\mathrm{O}+\mathrm{R}$, resistin + odanacatib.

ODN treatment increases the phosphorylation of LKB1 and AMPK decreased by resistin

To further investigate the underlying molecular mechanism by which OND inhibits resistin-induced cardiomyocyte hypertrophy, we evaluated the phosphorylation status of LKB1 and AMPK following resistin and ODN treatment by western blot. Treatment of resistin decreased phosphorylation of LKB1 and AMPK, whereas total LKB1 and AMPK protein expression was unchanged. Treatment of ODN increased expression of phosphorylated LKB1 and AMPK that was decreased by resistin (Fig. 4). 


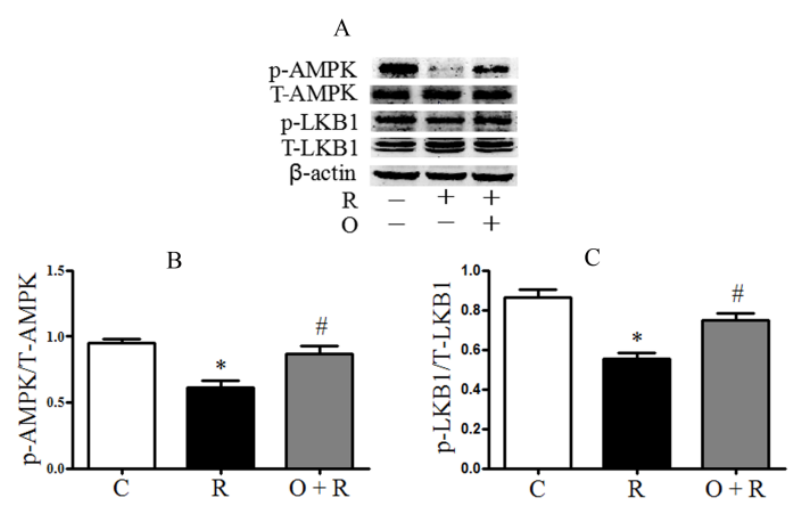

Figure 4 - ODN reverses the effects of resistin that decreases phosphorylated LKB1 and AMPK expression. (A) Representative western blot. (B) The expression of p-AMPK normalized with AMPK. (C) The expression of pLKB1 normalized with LKB1. Data represent the mean \pm SD. $* p<0.01$ vs. the control group, \#p $<0.01$ vs. the resistin group. $\mathrm{C}$, control; $\mathrm{R}$, resistin; $\mathrm{O}+\mathrm{R}$, resistin + odanacatib.

\section{DISCUSSION}

Many cardiovascular diseases such as coronary heart disease, hypertension, heart valve disease, are accompanied by varying degrees of cardiac hypertrophy. Finally, they develop into a heart failure. This is a serious threat to the lives of patients. Therefore, it is great significant to study the mechanism of cardiac hypertrophy for the diagnosis, treatment and prognosis of cardiac hypertrophy and heart failure.

Resistin is a kind of adipokine. In recent years, more and more researches about resistin and cardiac hypertrophy have been studied. Excessive expression of resistin is associated with cardiac remodeling and dysfunction in rat ${ }^{10}$. Serum resistin levels are higher significantly in patients with hypertrophic cardiomyopathy ${ }^{20}$. Resistin overexpression can lead to the increase of the volume of myocardial cells, protein synthesis, the expression of hypertrophy marker ANP, BNP and $\beta-\mathrm{MHC}$, which are through AMPK/mTOR and JNK/IRS1 signaling pathways ${ }^{21}$. Resistin can also induce myocardial hypertrophy through activating IRS1/MAPK signaling pathway ${ }^{22}$. In our present study, resistin treatment could increase cell surface area, protein synthesis, expression of BNP and $\beta-\mathrm{MHC}$, which were consistent with the results of previous studies.

LKB1 is a serine/threonine protein kinase that is expressed in almost all human tissues. LKB1 is a tumor suppressor gene closely related to the occurrence of many kinds of tumors ${ }^{23}$. The activation of LKB1 requires the binding of MO25 and STRAD to the complex ${ }^{24}$. The main function of LKB1 is to inhibit cell proliferation and promote cell apoptosis by inhibiting cell cycle in the G1 phase. LKB1 can phosphorylate downstream AMPK at threonine 172 to activate AMPK. LKB1 is discovered to be the key upstream activator of the AMPK ${ }^{25}$.

AMPK is a serine/threonine protein kinase, which is widely existed in eukaryotes. It is formed by the three subunit of $\alpha, \beta$ and $\gamma^{26}$. The activation of AMPK is mainly regulated by the intracellular AMP/ATP ratio, which is an intracellular energy regulator ${ }^{27}$. Any factors that lead to the increase of AMP/ATP ratio, such as metabolism, oxidative stress, ischemia and hypoxia, can activate the phosphorylation of AMPK. Many studies show that AMPK is closely related to cardiac hypertrophy. The activity of AMPK is significantly decreased in hypertrophic cardiac myocytes, and AMPK can limit the protein synthesis and the remodeling of the cytoskeleton, which can inhibit cardiac hypertrophy ${ }^{28}$. EGCG prevents phenylephrine-induced myocardial hypertrophy through activating AMPK signaling pathway ${ }^{29}$. MicroRNA-451 promotes high fat diet induced myocardial hypertrophy by inhibiting the LKB1/AMPK signaling pathway ${ }^{30}$. 
ODN inhibits resistin-induced myocyte hypertrophy

Cathepsin $\mathrm{K}$ is a lysosomal protease involved in various biological activities. The expression of cathepsin $\mathrm{K}$ in myocardium of rats with heart failure is significantly higher than that in normal rats. Cathepsin $\mathrm{K}$ deficiency can effectively relieve pressure overload cardiac hypertrophy ${ }^{31}$. Cathepsin $\mathrm{K}$ induces cardiac hypertrophy by activating the mTOR signaling pathway. Cathepsin $\mathrm{K}$ gene knockout can inhibit the hypertrophy and apoptosis of cardiomyocytes, but does not change the myocardial fibrosis ${ }^{32}$. ODN is an inhibitor of cathepsin K. Through the experiments using ODN to intervene resistin-induced cardiomyocyte hypertrophy, we found that cell surface area, protein synthesis, BNP and $\beta$-MHC expression were significantly decreased, while LKB1 and AMPK phosphorylation levels were significantly increased after treatment with ODN and resistin.

\section{CONCLUSION}

Resistin can increase cardiomycyte size, protein synthesis and hypertrophic marker $\mathrm{BNP}$ and $\beta$-MHC mRNA expression. Resistin also decreases the activation of LKB1/AMPK pathway. Whereas ODN reverses these effects of resistin, suggesting ODN can inhibit resistin-induced H9c2 cell hypertrophy through the activation of LKB1/AMPK signaling pathway.

\section{ACKNOWLEDGMENT}

This work was supported by the Key Research and Development Program of Shanxi Province (Grant No. 201603D321057), Scientific Research Foundation of Health and Family Planning Commission of Shanxi Province, China (Grant No. 201601093) and Basic and Cutting-Edge Technology Research Program of Henan Province (Grant No. 142300410118). Dr. Yongzhi Deng and Dr. Lin Wu contributed this work equally.

\section{REFERENCES}

1.Zhang C, Wang F, Zhang Y, Kang Y, Wang H, Si M, Su L, Xin X, Xue F, Hao F, Yu L, Xu J, Liu Y, Xue M. Celecoxib prevents pressure overload-induced cardiac hypertrophy and dysfunction by inhibiting inflammation, apoptosis and oxidative stress. J. Cell. Mol. Med. 2016;20:116-127

2.Liou SF, Hsu JH, Chen YT, Chen IJ, Yeh JL. Kmup-1 attenuates endothelin-1-induced cardiomyocyte hypertrophy through activation of heme oxygenase-1 and suppression of the akt/gsk-3beta, calcineurin/nfatc4 and rhoa/rock pathways. Molecules. 2015;20:1043510449

3. Karakikes I, Kim M, Hadri L, Sakata S, Sun Y, Zhang W, Chemaly ER, Hajjar RJ, Lebeche D. Gene remodeling in type 2 diabetic cardiomyopathy and its phenotypic rescue with serca2a. PLoS One. 2009;4:e6474

4.Graveleau C, Zaha VG, Mohajer A, Banerjee RR, Dudley-Rucker N, Steppan CM, Rajala MW, Scherer PE, Ahima RS, Lazar MA, Abel ED. Mouse and human resistins impair glucose transport in primary mouse cardiomyocytes, and oligomerization is required for this biological action. J. Biol. Chem. 2005;280:31679-31685

5.Rothwell SE, Richards AM, Pemberton CJ. Resistin worsens cardiac ischaemiareperfusion injury. Biochem. Biophys. Res. Commun. 2006;349:400-407

6. Chemaly ER, Kang S, Zhang S, McCollum L, Chen J, Benard L, Purushothaman KR, Hajjar RJ, Lebeche D. Differential patterns of replacement and reactive fibrosis in pressure and volume overload are related to the propensity for ischaemia and involve resistin. J. Physiol. 2013;591:5337-5355 
7.Jamaluddin MS, Weakley SM, Yao Q, Chen C. Resistin: Functional roles and therapeutic considerations for cardiovascular disease. Br. J. Pharmacol. 2012;165:622-632

8. Jamaluddin MS, Yan S, Lu J, Liang Z, Yao Q, Chen C. Resistin increases monolayer permeability of human coronary artery endothelial cells. PLoS One. 2013;8:e84576

9. Cho Y, Lee SE, Lee HC, Hur J, Lee S, Youn SW, Lee J, Lee HJ, Lee TK, Park J, Hwang SJ, Kwon YW, Cho HJ, Oh BH, Park YB, Kim HS. Adipokine resistin is a key player to modulate monocytes, endothelial cells, and smooth muscle cells, leading to progression of atherosclerosis in rabbit carotid artery. J. Am. Coll. Cardiol. 2011;57:99-109

10.Chemaly ER, Hadri L, Zhang S, Kim M, Kohlbrenner E, Sheng J, Liang L, Chen J, P $\mathrm{KR}$, Hajjar RJ, Lebeche D. Long-term in vivo resistin overexpression induces myocardial dysfunction and remodeling in rats. J. Mol. Cell. Cardiol. 2011;51:144-155

11.Qin Y, Shi GP. Cysteinyl cathepsins and mast cell proteases in the pathogenesis and therapeutics of cardiovascular diseases. Pharmacol. Ther. 2011;131:338-350

12.Li Z, Hou WS, Bromme D. Collagenolytic activity of cathepsin k is specifically modulated by cartilage-resident chondroitin sulfates. Biochemistry. 2000;39:529-536

13.Shi GP, Munger JS, Meara JP, Rich DH, Chapman HA. Molecular cloning and expression of human alveolar macrophage cathepsin s, an elastinolytic cysteine protease. J. Biol. Chem. 1992;267:7258-7262

14.Cheng XW, Huang Z, Kuzuya M, Okumura K, Murohara T. Cysteine protease cathepsins in atherosclerosis-based vascular disease and its complications. Hypertension. 2011;58:978-986

15.Cheng XW, Shi GP, Kuzuya M, Sasaki T, Okumura K, Murohara T. Role for cysteine protease cathepsins in heart disease: Focus on biology and mechanisms with clinical implication. Circulation. 2012;125:1551-1562

16.Zhao G, Li Y, Cui L, Li X, Jin Z, Han X, Fang E, Gao Y, Zhou D, Jiang H, Jin X, Piao G, Li X, Yang G, Jin J, Zhu E, Piao M, Piao L, Yuan K, Lei Y, Ding D, Jin C, Nan Y, Cheng $\mathrm{X}$. Increased circulating cathepsin $\mathrm{k}$ in patients with chronic heart failure. PLoS One. 2015;10:e0136093

17.Stoch SA, Zajic S, Stone JA, Miller DL, van Bortel L, Lasseter KC, Pramanik B, Cilissen C, Liu Q, Liu L, Scott BB, Panebianco D, Ding Y, Gottesdiener K, Wagner JA. Odanacatib, a selective cathepsin $\mathrm{k}$ inhibitor to treat osteoporosis: Safety, tolerability, pharmacokinetics and pharmacodynamics--results from single oral dose studies in healthy volunteers. Br. J. Clin. Pharmacol. 2013;75:1240-1254

18.Liu P, Cheng GC, Ye QH, Deng YZ, Wu L. Lkb1/ampk pathway mediates resistininduced cardiomyocyte hypertrophy in h9c2 embryonic rat cardiomyocytes. Biomedical reports. 2016;4:387-391

19.Zhuo Y, Gauthier JY, Black WC, Percival MD, Duong LT. Inhibition of bone resorption by the cathepsin k inhibitor odanacatib is fully reversible. Bone. 2014;67:269-280

20.Hussain S, Asghar M, Javed Q. Resistin gene promoter region polymorphism and the risk of hypertrophic cardiomyopathy in patients. Transl. Res. 2010;155:142-147

21.Kang S, Chemaly ER, Hajjar RJ, Lebeche D. Resistin promotes cardiac hypertrophy via the amp-activated protein kinase/mammalian target of rapamycin (ampk/mtor) and c-jun n-terminal kinase/insulin receptor substrate 1 (jnk/irs1) pathways. J. Biol. Chem. 2011;286:18465-18473

22.Kim M, Oh JK, Sakata S, Liang I, Park W, Hajjar RJ, Lebeche D. Role of resistin in cardiac contractility and hypertrophy. J. Mol. Cell. Cardiol. 2008;45:270-280

23.Pooya S, Liu X, Kumar VB, Anderson J, Imai F, Zhang W, Ciraolo G, Ratner N, Setchell KD, Yoshida Y, Jankowski MP, Dasgupta B. The tumour suppressor lkb1 regulates myelination through mitochondrial metabolism. Nature communications. 2014;5:4993

24.Baas AF, Boudeau J, Sapkota GP, Smit L, Medema R, Morrice NA, Alessi DR, Clevers HC. Activation of the tumour suppressor kinase lkb1 by the ste20-like pseudokinase strad. EMBO J. 2003;22:3062-3072

25.Momcilovic M, Shackelford DB. Targeting lkb1 in cancer - exposing and exploiting vulnerabilities. Br. J. Cancer. 2015;113:574-584

26.Heidrich F, Schotola H, Popov AF, Sohns C, Schuenemann J, Friedrich M, Coskun KO, von Lewinski D, Hinz J, Bauer M, Mokashi SA, Sossalla S, Schmitto JD. Ampk - 
ODN inhibits resistin-induced myocyte hypertrophy

activated protein kinase and its role in energy metabolism of the heart. Curr. Cardiol. Rev. 2010;6:337-342

27.Bertoldo MJ, Faure M, Dupont J, Froment P. Ampk: A master energy regulator for gonadal function. Front. Neurosci. 2015;9:235

28.Fassett JT, Hu X, Xu X, Lu Z, Zhang P, Chen Y, Bache RJ. Ampk attenuates microtubule proliferation in cardiac hypertrophy. Am. J. Physiol. Heart Circ. Physiol. 2013;304:H749-758

29.Cai Y, Zhao L, Qin Y, Wu XQ. Egcg blocked phenylephrin-induced hypertrophy in h9c2 cardiomyocytes, by activating ampk-dependent pathway. Korean J. Physiol. Pharmacol. 2015;19:203-210

30.Kuwabara Y, Horie T, Baba O, Watanabe S, Nishiga M, Usami S, Izuhara M, Nakao T, Nishino T, Otsu K, Kita T, Kimura T, Ono K. Microrna-451 exacerbates lipotoxicity in cardiac myocytes and high-fat diet-induced cardiac hypertrophy in mice through suppression of the lkb1/ampk pathway. Circ. Res. 2015;116:279-288

31.Hua Y, Xu X, Shi GP, Chicco AJ, Ren J, Nair S. Cathepsin k knockout alleviates pressure overload-induced cardiac hypertrophy. Hypertension. 2013;61:1184-1192

32.Hua Y, Robinson TJ, Cao Y, Shi GP, Ren J, Nair S. Cathepsin k knockout alleviates aging-induced cardiac dysfunction. Aging cell. 2015;14:345-351 